\begin{tabular}{lc}
\hline & ANNALES \\
& UNIVERSITATIS MARIAE CURIE-SKŁODOWSKA \\
VOL. VI & LUBLIN - POLONIA \\
\hline
\end{tabular}

ISSN: 2451-0491 • e-ISSN: 2543-9340 - CC-BY 4.0 • DOI: 10.17951/en.2021.6.377-394

\title{
Development of the Early Support System for Young Children in Ukraine: The Periods of System Formation
}

\author{
Rozwój systemu wczesnego wspomagania małych \\ dzieci na Ukrainie. Okresy tworzenia
}

\author{
Svitlana Khomenko \\ Oles Honchar Dnipropetrovsk National University \\ 72 Gagarin Av., Dnipro, Dnipropetrovsk region, Ukraine, 49000 \\ svitlana.aspirantka@ukr.net \\ https://orcid.org/0000-0002-1443-8308
}

\begin{abstract}
Abstrakt. W artykule analizie poddano rozwój systemu wczesnego wspomagania małych dzieci, który jest integralną częścią ukraińskiej polityki państwowej w dziedzinie edukacji i praw dziecka zdefiniowanych w prawie międzynarodowym i krajowym, a także etapy jego powstawania. Wczesne wspomaganie rozpatrywane jest jako interdyscyplinarny, skoncentrowany na rodzinie, kompleksowy system wsparcia małych dzieci z niepełnosprawnością rozwojową oraz dzieci z grup ryzyka biologicznego i społecznego. Celem tego systemu jest poprawa rozwoju dzieci i jakości życia ich rodzin przy pomocy specjalnych instytucji, organizacji i ich oddziałów, które podlegają Ministerstwu Edukacji oraz Ministerstwu Zdrowia i Opieki Społecznej Ukrainy. Przeanalizowano naważniejsze przepisy znajdujące się w międzynarodowych i krajowych aktach prawnych dotyczące wczesnego wsparcia dzieci ze specjalnymi potrzebami edukacyjnymi w różnym wieku. Ponadto określono etapy kształtowania się systemu i opisano praktyki wczesnego wspomagania dzieci ze specjalnymi potrzebami edukacyjnymi na każdym etapie ich rozwoju.
\end{abstract}

Słowa kluczowe: system wczesnego wspomagania małych dzieci; polityka państwowa; wczesne wspomaganie; małe dzieci; dzieci ze specjalnymi potrzebami edukacyjnymi 


\begin{abstract}
The article examines the formation of the early support system for young children as an integral part of Ukraine's state policy in the field of education and children's rights, the international and national legislation that defines this system, and the stages of its formation. Early support is understood as an interdisciplinary family-centred comprehensive support system for young children with developmental disabilities or biological or social risks. The aim of this system is to improve children's development and their families' quality of life with the help of special institutions, organisations and their subdivisions of different subordination: the Ministry of Education, the Ministry of Health and Social Protection of Ukraine. The main provisions declared in international and national legal documents concerning early support for children with special educational needs at different age periods are analysed and the stages of system formation are defined. The practices of early support for children with special educational needs at each formation stage are described.
\end{abstract}

Keywords: early support system for young children; state policy; early support; young children; children with special educational needs

\title{
INTRODUCTION
}

Many different branches of modern scientific knowledge examine the early stages of human development. After all, the future of each person, their family and the state as a whole depends on whether children are born healthy, in what conditions they are brought up and educated, or what opportunities they have for personal development.

Early support for children with special educational needs occupies a leading position in special pedagogy and psychology as one of the most important theoretical and practical up-to-day trends. According to the legal term (as it was accepted in 2010), children under 18 with "special educational needs" constitute a highly problematic group for the health and educational organisations, because they need additional educational, medical and social support to improve their health, development, training, general quality of life and socialization. In other words such children need comprehensive support from the very birth (Inklyuzivne...). Important personal traits are formed in the earliest years of a child's life; a life path is set here.

Thus, the system of special education must be reorganized and renewed based on the principles of democratization and humanization, recognition of every child's right to obtain education adequate to their cognitive abilities and current requirements of society. Based on the research results of foreign (S. Baret, M. Guralnik, T. Moore, N. Dobrova-Krol) scientists and international experience, this task can be realized through implementation of the early support system for children from the earliest years of life (Dobrova-Krol 2014). 
The purpose of the article is to trace the formation of the early support system for young children in Ukraine, to determine its stages on the basis of generalization of the national theory and practice of special pedagogy and psychology. The legal aspect will also be taken into account. To achieve this purpose, we identified the following tasks: on the basis of the review of national and foreign special literature, as well as on the basis of legislative documents - to clarify the appropriateness of the term "early support" in comparison with other terms; to identify and briefly describe the stages of early support system formation in such areas as education, social protection, health care, and to reveal potential resources for further development.

\section{REVIEW OF RECENT STUDIES}

The theory and practice of special pedagogy prove the importance of early detection and correction of children's developmental disorders. It has been confirmed by foreign (Winnicott, Brutman and Filippova, Lyakso, Guslova and Sture) and domestic (Arkhipova, Aksonova, Vygotsky, Mastyukova, Razenkova, Strebeleva) scientists. Therefore, the practical provision of early support to children with special educational needs in Ukraine has become a top priority in the modern system of special education. This position is based on L. Vygotsky's cultural-historical theory and his scientific school, whose representatives (e.g. L. Bozhovych, O. Zaporozhets, O. Leontiev, D. Elkonin) proved the uniqueness of the first years of children's life as far as their development is concerned. Many authors (S. Mironova, V. Ragozina, O. Solomka, V. Martyniuk, R. Moiseenko, G. Kukuruza, M. Kropivnytska) consider early support as a new direction in national special education, developed on the basis of the multidisciplinary approach, implementing the ideas of humanistic and personality-oriented education. In other words, early support provided for children from 0 to 3 years of age, when personal qualities and traits are intensively formed (L. Vygotsky, L. Wenger, O. Zaporozhets, D. Elkonin), creates conditions for effective physical, psychological and personal development of children and helps to provide them with equal educational rights in the future. It refers to all children, including those with special educational needs, children with disabilities, or children from other socially vulnerable groups. The complete development of each child (from the time of their birth according to their individual capabilities) is their inalienable human right and one of the most important goals of public policy. It is a field where the interests of parents, health workers, teachers, psychologists, various social institutions, government agencies, etc. are closely intertwined. Therefore, the transformation of an educational institution as a whole should 
be aimed at equal participation of all children in the process of education, and all school staff, as well as parents, children, society should be participants of this process. Inclusive education, as an alternative to special education, should provide equal educational opportunities for all children, and, at the same time, their fullest socialization. According to the statistics received since 2015 by the order of the Ministry of Education and Science of Ukraine, as of January 1, 2020, 4,681 children with special educational needs studied in inclusive preschool education institutions. Today, inclusive classes enrolment is on the rise. This kind of education was introduced by the Ministry of Education and Science in 2011, and 19,345 pupils are enrolled in schools which provide this system of education. This is seven times more than five years ago. This fact indicates that early support, as part of the educational system in Ukraine, should be further developed, because the tasks of this system remain completely unrealized in practice (Statistichni dani).

It is crucial to provide early support for children already at the very early stage of their life (G. Kukuruza, O. Lemekh, S. Mironova). This is the moment when children's development takes place naturally. Early support helps to identify children's developmental disorders, initiate correctional work with them, activate their compensatory processes, improve their emotional and volitional condition. It also alleviates or eliminates violations and prevents the emergence of secondary disorders. It serves, in general, the basis for inclusive education and ensures the continuity of inclusive preschool and school education. Thus, the development of the early support system for children in Ukraine, with the participation of their parents, social institutions and the state can be considered as a relevant task for special pedagogy and psychology. This new link in the special education system creates prospects for further education of children with special educational needs and for their future professional work.

\section{RESEARCH METHODS AND TECHNIQUES}

The following methods were used for article preparation: theoretical analysis, synthesis and generalization of legal documents, manuals and other textual thematic materials on topical issues of early support for children up to the age of 3 with special educational needs, which describe comprehensive support for such children's development and normalization of their families' lives. 


\section{PRESENTATION OF THE MAIN MATERIAL}

The phrase "early support" implies that it is provided at the earliest stages of a child's development ( $0-3$ years). A child's brain is plastic and can respond positively to external influences, while minimizing the stress experienced by families because of the birth of a child with special educational needs.

The encyclopaedic literature defines linguistically the words "support" and "assistance" (which are used in Ukrainian as synonyms) as assistance, support (physical, material, moral, etc.) in something that brings relief (Ozhegov and Shvedova 2004); participation in any work, facilitation, assistance for someone, providing support (Ushakova 1996: 752); physical participation of someone in an action performed by someone else; support, assistance in the implementation of any event; material support; protection of someone, rescuing somebody from trouble; assistance in treatment, alleviation of suffering, helping someone (Bilodid 1970-1980).

Such an interpretation of the term "support" allows us to distinguish its different types: medical, legal, material, social, psychological, socio-pedagogical, and so on. It should be noted that the terms "early correctional support", "early intervention", "social-pedagogical patronage", "early care", "early abilitation", "psychological and pedagogical support", etc. are used in the field of education, but they are not completely consistent. The terms "early social rehabilitation" and "early socialization" are used in the social protection system, which is aimed at disabled children under 7 years and children under 2 years who are at risk of developmental delay. Such terms as "medical and social rehabilitation", "early rehabilitation", "early abilitation" are used in the field of health care, where the work is aimed at health and treatment of disorders in 0-3-year-old children.

In Europe, the United States and Canada, the term "early intervention" is common. The corresponding activities have several names: Early Childhood Intervention (ECI), Early Aid (EA), Early Support. In many countries, different terms are used simultaneously: there are socio-paediatric centres in Germany (in the health care system) that provide early intervention services, and early assistance centres (in the education system); "early intervention" and "early support" are used interchangeably in Ukraine.

The word "intervention" has three meanings: intervention, mediation and compassion (Bilodid 1970-1980). In Ukrainian, the term "intervention" is interpreted as an active attitude to something, i.e. it indicates the organizational component of a process, whereas "mediation" and "compassion" mean to be close to someone or something, i.e. they are focused on the content component, agents' interactions in general, and according to M. Kropivnytska (2019: 132-137), the 
terms are twofold and can ensure the procession integrity in relation to children and their families.

Today, there are different interpretations of the term "early intervention" in Europe and the United States. It depends on different scientific schools and approaches, a particular historical period, the definition of their main features that are expanded and complemented. According to the European Association on Early Childhood Intervention (EURLYAID), early intervention means actions aimed at young children's development, support of the children's parents, as well as other family members and the social environment as a whole; programs for early childhood intervention (WHO 2012); early intervention is a system of coordinated services that helps children with developmental delay and supports families during the critical early years (Overview... 2017). It is a system of comprehensive, interdisciplinary, family-centred assistance for children from birth to 3 years of age who have developmental disabilities or risk of their occurrence, aimed at children's development and the normalization of their family life (Bayda et al. 2017: 62; Dobrova-Krol 2014: 48).

Thus, today there is no single definition of "early intervention" (N. Mikhanovskaya, G. Kukuruza, A. Kravtsova). It is an interdisciplinary family-centred support system for young children with developmental disabilities and children at biological and social risk, aimed at improvement of their development and improvement of the quality of their family life. The terms "early intervention" and "early assistance" can be used almost interchangeably, because they combine attitudes existing in different countries to people with special educational needs and to their families (Mikhanovska et al. 2005: 29).

Since early support is really needed in case of children with special educational needs and early support systems are widely organized in the world practice, let us present the retrospective analysis of the origins of early support system in Ukraine from old times to the present.

The Christianization of the Slavic world had a decisive influence on all life spheres of human life, including social relations, which naturally affected the character, forms of helping people, and caring for the poor and infirm. Since then, the Christian concept of help, based on the philosophy of love for a neighbour, began to take shape. Since the times of Kievan Rus, the Slavs had compassionate attitudes towards people with severe physical and mental disabilities. Later, legislation emerged to help different categories of the population. In the $18^{\text {th }}$ century, there also appeared baby hatches ("windows of life") - a special place where people can bring babies and abandon them anonymously. During this period, humanistic tendencies were formed in Europe by many philosophers and teachers (J. Locke, J.-J. Rousseau, F. Fröbel, F. Diesterweg, J. Komenský), 
who presented the ideas of early assistance in the context of humanist pedagogy, in its historical educative systems. Until the $19^{\text {th }}$ century, no one tried to teach or treat children with developmental problems, but later the humanistic tendencies in medicine were implemented in the medical model of assistance, which focused on the treatments of children's developmental disorders, their consequences and existed until the 1960s.

The national systems of special education in Eastern and Western European countries were formed depending on the corresponding socio-cultural living conditions and changes in the states' attitudes to people with physical or mental disabilities, which were changed over time. The comparative study (V. Bondar, A. Kolupaeva, M. Malofeev) on the evolution of societies' and states' attitudes to people with special needs in Western countries revealed five periods, whose conditional boundaries are historical events that significantly influenced status of people with disabilities. These periods cover two and a half thousand years the path from hatred and aggression to acceptance, partnership and integration (Kolupaeva 2009).

The historical and pedagogical sources indicate that till the 1970s, Western Europe had moved from understanding of the need for special education for deaf, blind, mentally retarded children to realizing the need to provide education for all children with disabilities. As a result, the preconditions for national systems of special education were formed, the network of special educational institutions started to operate. Such institutions became more differentiate and there appeared a conviction that children with special educational needs should be provided with special support from the early years of life. The very term "children with special educational needs" was proposed in the late 1970s by British experts, and it was proved that such children's failure to meet generally accepted social expectations, educational standards of success, established social norms of behaviour and communication can only be overcome by socio-pedagogical assistance in education.

The works of foreign researchers on the issues of: infants' social-emotional development (Bowlby, Winnicott), mother-infant interaction (Fogel, Stern), a mother's influence on the relationship with her child, their course and interactions, development of infants whose mothers suffer from mental disorders or are in a social risk (Field, Beckwith), constitute a significant contribution to raising awareness of the need for early support for children with special educational needs.

Thus, the analysed foreign and national historical, pedagogical and scientific works show the dynamics of relations between children and parents, a new philosophy in education, the establishment of humanistic values (on the basis of which a new idea on children with special educational needs appeared), the 
value of their education, the importance of early periods, their role in personal development, as prerequisites for the development of early assistance concept.

The right to education for all people who could become useful members of society was proclaimed at the $23^{\text {rd }}$ Geneva International Conference on Public Education (1960). The achievements in medicine, psychology, special pedagogy should be used as early as possible early to detect mentally retarded children and to provide them with proper education using the methods based on differentiation and individualization of education. This right was enshrined in the Convention against Discrimination in Education (1960) and the International Convention on the Elimination of All Forms of Racial Discrimination (1965), which further led to the introduction of the concepts of Open Civil Society and Unhindered Access to Education. Based on these Conventions, the USA and many European countries (Germany, the UK, France, Sweden, Denmark, the Netherlands, Finland, etc.) had justified the need to create conditions for children's development and education from their birth much earlier than it was done in Ukraine. According to O. Emelina (2013), early intervention, as an early support system for children with special educational needs, has been developing in Europe and the United States since the 1950-1960s and covers the following periods: the first one (from the 1960s to the 1980s) was characterized by new ideas of the valuable social and family influence and children's development from their birth; the second period (from the 1990s to the present) is characterized by the holistic social-pedagogical approach to a child's personality and meeting young children's special needs in education and socialization (Emelina 2013: 49-55).

In Eastern Europe, before the Russian Revolution of 1917, the ideas on children's education from their early age were expressed by I. Sikorsky, A. Lazursky, P. Blonsky and other scientists. Nurseries, as a form of care for young children, appeared and became widespread in cities and villages. The founders of nurseries in cities were individuals, societies, doctors, public, or country councils. The initiators of early correctional work for children were educators of the deaf (F. Rau, N. Rau, M. Bogdanov-Berezovsky), who opened the first specialized nursery, and developed methodological literature on the education and development of young children with hearing impairment. V. Bekhterev, a neurologist and psychiatrist (1920), recognized the need for a comprehensive approach to studies on children and their development from their birth.

In the 1920s and 1930s, the indicators of children's neuropsychological development during the first year of life (including deviations from the norm) were developed in the clinic of Prof. M. Shchelovanov. Later, they were revised and supplemented from time to time by the scientific team led by Prof. $\mathrm{N}$. Aksarina. Then, the early childhood educational system was built on the 
basis of scientific research performed at the Institute of Paediatrics, Academy of Medical Sciences of the USSR, as well as at the Central Institute for Advanced Training of Physicians (1950), the Department of Children's Physiology and Education, headed by Prof. Shchelovanov, Prof. Aksarina (1967) and others.

The archival materials analysed by V. Zolotoverkh shows that public education of young children was introduced in the second half of the $19^{\text {th }}$ century (Zolotoverkh 2002: 50-53). Ukraine was a part of the USSR, where the public education for young children, which had a certain history of development, had been functioning in state institutions such as nurseries and kindergartens.

The early detection and correction of developmental disorders is a fundamental principle of Ukrainian special pedagogy. This principle derives from the leading role of education for children's development determined by L. Vygotsky (2003: 127). According to European scholars (J. Johnson, W. Miller and W. Mills), L. Vygotsky's cultural-historical theory of higher mental function development is in tune with the ideas of social inclusion, which are the theoretical basis of early support programs and serve as a source for the integration theory. These theories and corresponding organizational forms of social-pedagogical work have become widespread and obtained legislative support in Western countries (Lipsky and Gartner 1996: 189; Peters 2003; Vygotsky 2003: 127).

Children with special educational needs were provided with correctional care, mainly according to the medical model, in special education institutions: specialized kindergartens, boarding schools, psychological-medical-pedagogical commissions, etc. In the field of health care, the aim was to improve the health and to treat disorders of 0-3-year-old children. In addition, medical care was more accessible (through the wide network of maternity hospitals, clinics, hospitals, sanatoriums, orphanages) compared to the social protection and education systems, because the medical model dominated, according to which a child with special needs was considered as a patient expecting a certain treatment.

In the 1970s, the theory and practice of early childhood support was further developed by medical and pedagogical specialists (N. Aksarina, M. Kistyakovskaya, M. Koltsova, N. Ladygina, M. Lisina, G. Lyamina, N. Figurin, F. Fradkina, M. Shchelovanov). The developed content, forms and methods were still the theoretical and methodological basis for working with young children. At the end of the 1980s, for the first time, the Ministry of Health in Ukraine developed a unified, mandatory system for early detection of children with hearing impairments, which was introduced in the country as mandatory (E. Leongard, T. Pelimska, N. Shmatko).

Until the 1990s, early support given to children from their birth in Ukraine was provided in the state institutions of education, health care and social 
protection. The policy of the Soviet state was focused on helping young children, mainly based on the medical model. The accumulated theoretical and practical experience of early childhood development was the basis for the modern early support.

The 1990s coincided with the collapse of the USSR, so Ukraine, as a post-Soviet country, experienced social-political changes in the state system during the period of gaining its independence. A new ideological socio-educational paradigm was defined at that time. The practice of early support was formed in the 1990s in a revolutionary form, with the transition from a unitary society to an open civil one (Nazarova, Morgacheva, and Furyaeva 2011: 335).

After adoption by the Verkhovna Rada of the Ukrainian Republic of the Declaration of State Sovereignty of Ukraine (July 16, 1990) and of the Act of Independence of Ukraine (August 24, 1991), the special education system passed several stages, whose time boundaries were determined by social, political and cultural processes in the country. During the first year of independence, an international treaty - Convention on the Rights of the Child (1991) - was ratified, Ukrainian legal framework began to be developed on the basis of this Convention. Primarily, it was applied to national educational legislation. The Convention became part of national legislation and facilitated the launch of the first stage of early support in the special educational system (1990-2000). A new developmental strategy for education was implemented based on such concepts as "society for all", and "education for all".

In 1993, the Institute of Special Pedagogy was organized to widen general understanding that special education should focus on the formation of a harmoniously developed personality based on the implemented social assistance model. The Institute staff developed, inter alia, the Concept of Special Education for Children with Special Needs for the Coming Years and Prospects (1996), the Concept of Rehabilitation of Children with Disabilities (1998), the Concept of the State Standard for Special Education (1999). The work of V. Bondar, L. Borshchevska, L. Vavina, O. Gavrilov, V. Zasenko, A. Kolupaeva, S. Myronova, V. Lypa, T. Sak, V. Sinyova, M. Supruna, V. Tarasun, L. Fedorovych, L. Fomichova, O. Khokhlina, A. Shevtsova, M. Sheremet and others was devoted to the development of the special education system and the early support system for young children. The realities of special education development put forward the task for pedagogical science and practice (V. Bondar, V. Sinyov) to find optimal conditions for teaching young children with different educational needs.

A joint Ukrainian-German health care project - the Ukrainian Medical Centre for Rehabilitation of Children with Organic Nervous System Disorders subordinated to the Ministry of Health of Ukraine - was launched in 1996, 
whereas the Concept on Improved Neurological Care for Ukrainian Children was approved in 1998. The model of medical and social rehabilitation for children with organic lesions of the nervous system ("Tandem-partnership", "Child-family-specialist") was also launched. It was based on the harmonious combination of medical and psychological-pedagogical aspects of rehabilitation (by a multidisciplinary team) (Martinyuk 2011: 1-4).

In parallel, the Ministry of Social Protection of Ukraine organized centres for social rehabilitation of children with disabilities, which became part of the professional social-paediatrics centres. Based on foreign experience the Training and Rehabilitation Centre "Dzherelo" was organized in 1993 with the help of Canadian volunteers and on the initiative of parents of children with cerebral palsy united into "Nadiya" Society. It was the first organization aimed at providing early intervention (Website...).

Later, the Centre for Early Social Rehabilitation of Disabled Children was opened in Mykolayiv (Mykolayiv Model of Early Intervention, 1996) on the initiative of the Fund for Social Protection of the Disabled and with the support of the Ministry of Labour and Social Policy of Ukraine. Ukrainian specialists have mastered the "Early Intervention" method during two years of cooperation with the Alvin Institute (the USA).

The early intervention program began to be implemented in Kharkiv in 1998 within the research project, whose main purpose was to study the world early intervention experience and create a model based on the international experience and domestic realities.

Thus, the appearance of the independent Ukraine and the corresponding changes of the state system led to the adoption of international ideas and instruments concerning children with special educational needs, which facilitated the implementation of foreign experience into early support practices during the first stage (1990-2000) of the formation of the early support system.

The second (2001-2010) stage was marked by a new methodological and socio-economic approach which appeared in relation to European integration and globalization, and initiatives which were proposed by the parent community and public organizations. This approach was based on the belief that all children can learn, receive quality education, realize their potential and be socialized.

When the Resolution "On the Approval of the Concept of Early Social Rehabilitation of Disabled Children" (2000), the laws "On Preschool Education" (2001) and "On Child Protection" (2001) were adopted, the efforts for early support were intensified. Early intervention centres began to be established as a system for interdisciplinary family-centred assistance. In 2000, in Kharkiv, the Centre for Early Intervention was established under the leadership of 
G. Kukuruza, where families having children with special educational needs caused by medical, biological and social factors received interdisciplinary assistance (Kukuruza 2013: 99-102).

In 2003, a regional association of parents having children with special needs was organised with the assistance of the U.S. Embassy in the framework of the project "Legal Protection of Disabled Children" (Rivne). This association of parents, together with the OMNI-Network and with the support of local authorities, initiated the creation of the Centre for Early Pedagogical Rehabilitation and Social Adaptation of Children with Special Educational Needs "Paginets" under the auspices of the local Department of Education. It was the first state institution authorised to offer early assistance in Ukraine (Bastun 2005: 184).

Under the laws "On State Social Standards and State Social Guarantees" (2000) and "On Social Services" (2003), a draft State Standard for the Early Intervention Service Quality for children aged 0 to 6 with developmental disorders and their families was developed in 2006. The draft initiators were the Institute of Early Intervention (Russia), the Ukrainian Social Investment Fund and the group of specialists working in the field of providing assistance for young children. During transition years, the nursery educational system was destructed almost completely, so the reform of preschool education for children with special needs only began in 2008. A new model of early support for children with special needs, which included the participation of their parents, was promoted due to the work of child development centres (Kukuruza 2013: 99-102).

One can find numerous approaches aimed at providing support for children with disabilities, For example, parents in Lutsk appealed to local authorities, so the regional Centre for Early Intervention was organized in 2006 within the structure of the existing orphanage. In Khmelnytsky, the Ukrainian Social Investment Fund, the Swedish International Development Agency (SIDA), local (city) authorities and the OMNI-Network organized the Information and Counselling Centre for families of children with special needs. A multidisciplinary team is made up of paediatricians, geneticists, psychologists, speech therapists, and social workers (Bastun 2005: 184).

In 2008, the Lviv Model of Early Intervention was launched as a comprehensive service system for families of children with disabilities or at risk of their development. The services are provided for children aged 0 to 4 years and include early detection, treatment and prevention of developmental disorders, as well as support for families. A multidisciplinary team of specialists works there (Remazhevska 2007).

The national project "New life - a New Quality of Maternity and Childhood Care" was implemented in the health care system, in accordance with the 
Presidential Decree of September 8, 2010. Its purpose was to help overcome the negative demographic trends. This project establishes a regional network of perinatal centres and reorganizes the medical care system for pregnant women and new-borns, ensuring the quality medical services for them to reduce infant and maternal mortality. The perinatal centre is a general clinic that provides consultations, treatment and rehabilitation of pregnant women, women in labour and new-borns. Such centres care for premature babies and provide them with specialized care using the latest medical technologies. Thus, the changes in the state educational policy as well as parents' involvement and support of international organizations stimulated the creation of local networks of perinatal, educational and rehabilitation centres.

The Concept on the Development of Inclusive Education was adopted in 2010. At the same time, the concept of inclusive education was introduced and defined in the legislative field as a comprehensive process ensuring equal access to quality education for children with special educational needs by organizing their education in secondary schools. For the first time, the term "special and inclusive classes" was introduced with the view of teaching children with special educational needs. Thus, the system of early detection and early comprehensive support for such children started to be created officially. This system became a new structural element of special education (Kolupaeva 2009: 272).

The need to develop early support as a system and a structural element of special education ensured a gradual transition to inclusive education and increased the number of "schools for all", which is characteristic to the third (2011 - the present day) stage of the formation of early support formation system in Ukraine. Inclusive education implements the right to education and health protection of children with special educational needs and takes into account their individual educational peculiarities. The Concept of Formation and Development of Disabled Preschoolers' Personality, developed by V. Tarasun, was especially important for pedagogical practice. Its main areas were determined by the state preschool education policy. Pursuant to the Concept of Preschool Education Development, the law of Ukraine "On Preschool Education" (2001), and the order "Additional Measures Improving Education Quality in Ukraine" (2008), preschool education was determined as a mandatory primary link in the education system. This means, first of all, provision of equal opportunities for all children in terms of obtaining education, correction and rehabilitation; children's early socialization and integration into society; conditions forming children's maximum possible cognitive-social competence from the first days of their life; the personality-oriented approach to children during correctional and developmental assistance both at preschool institutions and home; psychological and pedagogical support to families. 
The modern special education in Ukraine is a comprehensive, branched and differentiated system with a vertical-horizontal structure. Its vertical structure is based on children's age characteristics and the general education programs. The vertical structure is divided into the following age periods: early childhood (from 0 to 3 years); preschool period (from 3 to $6-7$ years); period of school and professional training (from 6-7 to 16-21 years). The horizontal structure takes into account children's psychophysical development, their cognitive peculiarities and the nature of their disorders. The main state educational institutions for children with special needs of preschool and school age are: special preschool and general boarding schools, educational and rehabilitation centres, educational complexes and inclusive groups and general educational institutions, etc. (Kolupaeva 2014:7-11).

The tasks regarding an early intervention system development in Ukraine were defined in the Parliamentary Hearing Recommendations "Education, Health and Social Security of Children with Mental and Physical Disabilities: Problems and Solutions" (2015) as urgent ones. The basis for them was the already existing scientific, practical and methodological achievement, provided in the resolutions "On Organization of an Early Intervention System in Ukraine for the Rehabilitation of First-Year Children" (2012) made by the Presidium of the National Academy of Medical Sciences of Ukraine. In order to implement the National Program "National Action Plan Implementing the UN Convention on the Rights of the Child", accepted in 2015, early intervention services and support for families raising children with disabilities were included in a pilot form up to 2016. In 2016, an agreement between the Ministry of Health of Ukraine, the Ministry of Education and Science of Ukraine, the Ministry of Social Affairs of Ukraine, the European Association for Early Intervention was signed to introduce a national early intervention platform. The National Assembly of People with Disabilities, the Institute for Early Intervention and the SOFT Tulip Foundation (Netherlands) and others participate in the work of this platform. The agreement supports the joint efforts of all institutions that signed the document to create a unified national early intervention platform that would coordinate the work of various authorities, international and national organizations. For the practical implementation of the agreement, the Cabinet of Ministers of Ukraine issued the Order "Some Issues of the Pilot Project on Creating of a System Providing Early Intervention Services to Ensure Children's Development, Their Health and Life" (2016) and approved the corresponding action plan. Now, early intervention services for children with health and development disorders, or at risks of their occurrence, and for families raising them are provided at the level of administrative-territorial authorities of Zakarpattia, Lviv, Odesa and Kharkiv regions (Panchenko and Zaplatinska 2018). 
Such services have already been launched in different public health, educational, social protection, and non-governmental organizations. According to the order of the Cabinet of Ministers of Ukraine "On the Appointment of a National Coordinator" (2019), the Ministry of Social Policy of Ukraine has appointed the national coordinator for the early intervention service implementation within the pilot project. At the same time, since 2016, specialists are being trained to provide such services within the UNICEF project "Training of Early Intervention Teams and Community Professionals". The teams are trained by the Charitable Foundation "Institute of Early Intervention" in Kharkiv with the support provided by the following organizations: the Educational and Rehabilitation Centre "Dzherelo" (Lviv), the Institute of Child and Adolescents Health Care of the National Academy of Medical Science of Ukraine, Kharkiv Regional Specialized Orphanage No. 1.

The latest institutional transformation in Ukraine regarding the early support system started on September 1, 2017. Psychological, medical and pedagogical consultative centres were converted into inclusive resource centres, which became fully operational since September 1, 2018, based on the two resolutions of the Cabinet of Ministers of Ukraine: "Approval of the Regulation for the Inclusive Resource Centres" (2017), and "Subventions from the State Budget to Local Budgets to Provide State Support to Persons with Special Educational Needs" (2018). Currently, the system of early intervention solves the following tasks: early detection of children with developmental problems; interdisciplinary comprehensive assessment of children's health and development, their psychological and cognitive capabilities and the capabilities of their parents and other family members; determination of children's and families' needs based on the diagnostic data and the development of individual corrective programs; provision of assistance for young children and their families; ensuring continuous cooperation between health and education institutions and families.

At the third (2011 - and till today) stage of system formation, the legal documents, as well as the scientific and theoretical bases for the Ukrainian early intervention system are developed and approved. The early support system for children from their birth is a comprehensive unified multidisciplinary (medical rehabilitation, psychological, psychotherapeutic assistance, speech therapy, social) service allowing specialist to identify and provide all necessary assistance.

\section{RESULTS AND DISCUSSION}

The performed study has demonstrated that early support proposed for children with special educational needs is deeply rooted in the socio-cultural tradition, and has a certain unique, "historical age". The emergence of Ukraine 
as an independent state supported the dynamic formation of the early support system for children with special educational needs. It can be divided into three stages. The first one (1990-2000) began with gaining the state independence and ratification of the corresponding international instruments. The second (2001-2010) stage was devoted to the development of new methodological principles, benefiting from other countries' experience in early intervention, and introduction of early support practice into health care, educational and social security systems. The concept of inclusive education (2010) was introduced at the third (from 2011 to the present day) stage. Now, inclusive education is defined as a comprehensive process that includes the early support system for children with special educational needs. The rapid development of the early childhood support system was ensured by: historical and pedagogical national experience, relevant state legislation and ratified international documents, and benefiting from other countries' experience gained in this field.

\section{CONCLUSIONS}

The performed study will contribute to the reformation of special education and modernization of the education system as a whole, namely:

- increased attention paid to the timely, comprehensive psychological-pedagogical assessment of children's development from an early age, and providing psychological, pedagogical, correctional and developmental services in accordance with the identified needs of children and modern challenges,

- regulation of interdepartmental integration and social partnership (involvement of parents and representatives of various departments, social institutions, services) in order to optimize early support with the aim to provide high-quality education,

- renewal of preschool education and all spheres of education in accordance with the modern requirements, in particular development of preventive assistance that reduces consequences of children's primary developmental problems and prevents appearance of secondary ones, based on best practices of national and foreign education.

We see the prospects for further study on the early support system in the development of comprehensive programs and methods that can be applied in practice in the unified state system of early detection aimed at children with special educational needs and their families in order to ensure a smooth scientific, technological, economic, social, and cultural progress. 


\section{REFERENCES}

\section{Literature}

Bastun, N.A. (2005). Sluzhbi rannogo vtruchannya v Ukraïni: shlyakh do integratsii [Early Support in Ukraine: The Path to Integration]. Kiïv: IKTs Lesta. (In Ukrainian)

Bayda, L.Yu., Pavlova, E.B., Ivanova, O.L., Kukuruza, G.V. (2017). Formuvannya politiki rannogo vtruchannya: treningoviy modul [Formulation of Early Engagement Policy: Training Module]. Kiïv: pik. (In Ukrainian)

Bilodid, I.K. (red.). (1970-1980). Slovnik ukraïnskö̈ movi [Dictionary of the Ukrainian Language] [v 11 t.]. Kiïv: Nauk. dumka. (In Ukrainian)

Dobrova-Krol, N. (2014). Rannee vmeshatelstvo: Klyuchevye aspekty i mezhdunarodnyy opyt [Early Intervention. Key Aspects and International Experience]. United Nations Children's Fund (UNICEF). Kiïv. (In Russian)

Emelina, O.I. (2013). Stanovlenie sistemy pomoshchi detyam rannego vozrasta za rubezhom [Development of the Early Support System for Young Children Abroad]. Spetsialnoe obrazovanie, vol. 3, 49-55. (In Russian)

Kolupaeva, A.A. (2009). Inklyuzivna osvita: realii ta perspektivi [Inclusive Education: Realities and Perspectives]. Kiïv: Sammit-Kniga. (In Ukrainian)

Kolupaeva, A.A. (2014). Spetsialna osvita v Ukraïni ta modernizatsiya osvitn'oï galuzi [Special Education in Ukraine and Modernization of the Education Sector]. Osobliva ditina: navchannya $i$ vikhovannya, vol. 3, 7-11. (In Ukrainian)

Kropivnitska, M.E. (2019). Vprovadzhennya poslugi rannogo vtruchannya na rivni pilotnikh oblastey v Ukraïni [Early Intervention Service Implementation at the Level of the Pilot Areas in Ukraine]. Investitsii: praktika ta dosad, vol. 6, 132-137, DOI: http://dx.doi.org/10.32702/2306-6814.2019.6.132.

Kukuruza, A.V. (2013). Rannee vmeshatelstvo - semeyno-tsentrirovannaya model' pomoshchi semyam, vospityvayushchim detey rannego vozrasta s narusheniyami razvitiya [Early Intervention - a Family-Centered Model of Helping Families Raising Young Children with Developmental Disabilities]. Psikhologiya, vol. 9, 99-102. (In Russian)

Lipsky, D., Gartner, A. (1996). School Reform and Inclusive Education. Baltimore: Paul H. Brookes Publishing.

Martinyuk, V.Yu. (2011). Sotsialna pediatriya v Ukraïni: kontseptsiya, zavdannya, perspektivi [Social Pediatrics in Ukraine: Concept, Tasks, Prospects]. Medichna gazeta Zdorov'ya Ukrä̈ni. Pediatriya, vol. 1, 1-4. (In Ukrainian)

Mikhanovska, N.G., Kukuruza, G.V., Kravtsova, A.M. et al. (2005). Protsedura otsinki rozvitku ditey rann'ogo viku v sistemi rann'ogo vtruchannya: metodichni rekomendatsii (Uzgodzheno AMN Ukraïni ta MOZ Ukraïni) [The Procedure of Assessment of the Early Childhood Support System: Recommendations]. Kharkiv. (In Ukrainian)

Nazarova, N.M., Morgacheva, E.N., Furyaeva, T.V. (2011). Sravnitelnaya spetsialnaya pedagogika: ucheb. posobie dlya stud. uchrezhdeniy vyssh. prof. obrazovaniya [Comparative Special Pedagogy. Textbook. Manual for Institutions of Higher Education]. Moskva: Izdatel'skiy tsentr Akademiya. (In Russian) 
Ozhegov, S.I., Shvedova, N.Yu. (2004). Tolkovyy slovar russkogo yazyka: 80000 slov i frazeologicheskikh vyrazheniy [Explanatory Dictionary of the Russian Language: 80,000 Words and Phraseological Expressions]. Rossiyskaya akademiya nauk. Institut russkogo yazyka im. V.V. Vinogradova. Moskva: ATEMP. (In Russian)

Peters, G. (2003). Inclusive Education: Achieving Education for All by Including Those with Disabilities and Special Education Needs. London: World Bank.

Ushakova, D. (red.). (1996). Tolkovyy slovar russkogo yazyka [Explanatory Language of the Russian Language] [v 4 t.]. T. 4; Moskva: TERRA. (In Russian)

Vygotskiy, L.S. (2003). Printsipy vospitaniya fizicheski defektivnykh detey. Osnovy defektologii [The Principles of Raising Physically Handicapped Children. Basics of Defectology]. Sankt-Peterburg - Moskva: Izd-vo Lan. (In Russian)

WHO. (2012). Early Childhood Development and Disability: A Discussion Paper.

Zolotoverkh, V.V. (2002). Istorichni aspekti rozvitku spetsialnoï osviti v zarubizhniy praktitsi (kinets XIX - pochatok XX st.) [Historical Aspects of the Development of Special Education Abroad: The End of the $19^{\text {th }}-$ Beginning of the $20^{\text {th }}$ Century)]. Defektologiya, vol. 2, 50-53. (In Ukrainian)

\section{Netography}

Inklyuzivne navchannya [Inclusive Education]. Ministerstvo osviti i nauki Ukraïni. Retrieved from: https://mon.gov.ua/ua/tag/inklyuzivne-navchannya [access: 16.03.2020]. (In Ukrainian)

Overview of Early Intervention. (2017). Center for Parent Information and Resources. Retrieved from www.parentcenterhub.org/repository/ei-overview [access: 22.03.2020].

Panchenko, T.L., Zaplatinska, A.B. (2018). Ranne vtruchannya yak sistema kompleksnoï dopomogi dityam rannogo ta doshkilnogo viku [Forward Intervention as a System of Complex Aid to Children of Early and Preschool Age]. Narodna osvita, vol. 3(36). Retrieved from: www.narodnaosvita.kiev.ua/?page_id5463 [access: 22.03.2020]. (In Ukrainian)

Remazhevska, V.M. (2007). Naukovo-organizatsiyni osnovi stvorennya sistemi rann'oï kompleksnoï dopomogi dityam z vadami zoru [Scientical-Organisational Bases for Creation of Early Complex Intervention System for Children with Visual Impairments]. Zbirniknaukovikh prats, vol. 4(6). Retrieved from: http://ap.uu.edu. ua/article/289 [access: 22.03.2020]. (In Ukrainian)

Statistichni dani [Statistical Data]. Retrieved from: https://mon.gov.ua/ua/statistichni-dani [access: 16.03.2020]. (In Ukrainian)

Website of the Training and Rehabilitation Centre "Dzherelo". Retrieved from: www. dzherelocentre.org.ua [access: 19.03.2020]. (In Ukrainian) 